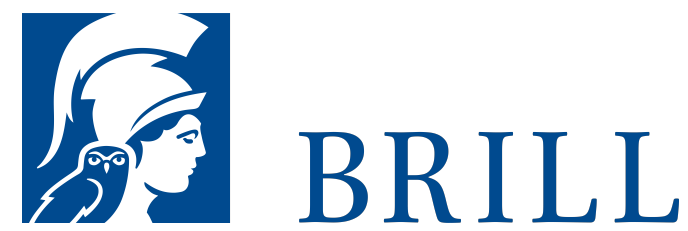

\section{International Investment Law in Latin America / Derecho Internacional de las Inversiones en América Latina}

\author{
Problems and Prospects / Problemas y Perspectivas
}

Editors: Attila Tanzi, Alessandra Asteriti, Rodrigo Polanco Lazo, and Paolo Turrini

With the bilingual volume International Investment Law in Latin America: Problems and Prospects, Attila Tanzi, Alessandra Asteriti, Rodrigo Polanco Lazo and Paolo Turrini provide a regional perspective on one of the liveliest branches of international law by situating it in one of the most dynamic areas of the world.

Latin America has always had an ambivalent relationship with international investment law and, more recently, it has been the home of harsh and resolute criticisms, questioning the ultimate legitimacy of the regime. By bringing together distinguished scholars of this legal field, the volume analyses ongoing trends and draws lessons from the Continent's past experiences while identifying possible solutions to the important challenges it faces.

Con el volumen bilingüe Derecho Internacional de las Inversiones en América Latina: Problemas y Perspectivas, Attila Tanzi, Alessandra Asteriti, Rodrigo Polanco Lazo y Paolo Turrini tienen por objetivo proporcionar una perspectiva regional para una de las ramas más vigorosas del derecho internacional, situándola en una de las áreas más dinámicas del mundo.

Latinoamérica siempre ha tenido una relación ambivalente con el derecho internacional de inversiones y, más recientemente, ha sido el hogar de duras y decididas críticas en su contra, cuestionando la legitimidad última del régimen. Al reunir a distinguidos estudiosos de...

See More

Readership

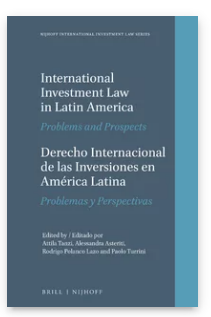

Pages: $\mathrm{xxx}, 869$

pp.

Language:

English

Subjects:

Private

International

Law / Conflict of

Laws,

International

Law,

International

Law: General

Interest,

International

Law

Publisher: Brill |

Nijhoff

Series:

Nijhoff

International

Investment Law

Series, Volume: 5

E-Book (PDF)

Released online:

15 Feb 2016

ISBN: 978-90-

04-31147-3

List price

USD $\$ 331.00$

Hardback

Publication date:

o3 Mar 2016 
Postgraduate students (especially but not exclusively in law faculties), academics, lawyers and arbitrators involved in investment-related disputes (including in-house counsels), international and national civil servants, policymakers, NGOs and informed public.

Estudiantes de postgrado (especialmente pero no exclusivamente en las facultades de derecho), académicos, abogados y árbitros que participan en los conflictos relacionados con inversión extranjera (incluyendo asesores internos), funcionarios internacionales y nacionales, responsables políticos, ONGs y público informado.
ISBN: $978-90-$ 04-31146-6 List price USD. $\$ 331.00$ 
Attila Tanzi, Ph.D. (1987, University of Rome "La Sapienza"), is Chair of International Law at the University of Bologna. He has been active in international litigation as counsel or arbitrator and has published on international responsibility, foreign investment law, environmental law and jurisdictional immunities.

Alessandra Asteriti, Ph.D. (2011, University of Glasgow), is Junior Professor of International Economic Law at Leuphana University and Post-doc Research Associate at the University of Glasgow. She has published in the areas of international investment law, legal theory and European law.

Rodrigo Polanco Lazo, Ph.D. (2015, University of Bern), LL.M. (New York University), Bachelor and Master of Laws (University of Chile), is a Lawyer, Assistant Professor of International Economic Law at the University of Chile, and Post-doc Research Scholar and Lecturer at the World Trade Institute - University of Bern. He has published in the areas of investment law, trade law and environmental law.

Paolo Turrini, Ph.D. (2013, University of Florence), is Post-doc Research Scholar at the School of International Studies of the University of Trento and collaborates with the Chair of International Law of the University of Bologna, School of Law.

For more information see brill.com

Order information: Order online at brill.com +44330 3330049 | customerservices@brill.com Submission information: brill.com/authors

Titles published by Brill | Fink, Brill | mentis or Brill | Schöningh: +49(o)71 5413279216 | brill@brocom.de 